\title{
Fiscal Policy for a Period of Transition
}

\author{
Remarks by the Honorable MURRAY L. WEIDENBAUM, Assistant Secretary \\ of the Treasury for Economic Policy, before the Annual Meeting \\ of the Board of Directors of the Federal Reserve Bank \\ of St. Louis, Little Rock, Arkansas, October 8, 1970
}

$\mathbf{I}_{\mathrm{T}}$

$\mathrm{T}$ IS a great personal pleasure for me to address this combined meeting of the Board of Directors of the Federal Reserve Bank of St. Louis and of its Little Rock branch. As a St. Louisian, I am keenly aware of the important contribution that this institution is making to our region.

As an economist, I am perhaps even more aware of the very useful role of the Eighth Federal Reserve District in emphasizing the importance of monetary factors in our national economy. I come here to pay tribute to the pioneering work of the Bank and its economists even though my own approach to economic policy may differ in some substantial respects.

I thought that it might be useful today if 1 prom vided some thoughts on that area of economic policy in which I have particular involvement, and that is fiscal policy. Before turning to the outlook for the economy and the budget, I would like to offer some personal observations on the role of fiscal policy.

Only a few years ago, it seemed that fiscal policy was all that mattered. Monetary considerations were largely ignored. In good measure because of the work of economists specializing in monetary policy, I believe that shortcoming has been corrected. As modem economists in general now realize, money, of course, does matter. However, as with many things in life, there is always the danger that the correction will be carried too far.

I sense a parallel here with the dentist who sees me as two rows of teeth surrounded by a lot of mis" cellaneous matter. Similarly, exclusive focus on a single economic variable, no matter how important, is bound to ignore significant characteristics of our complicated economic structure. The fiscal position of the Government, of course, is also important in economic policy, and from at least two standpoints. On the one hand, government spending and taxing have a direct impact on the levels of income and output in the economy and, hence, on the allocation of resources. On the other hand, there is the fiscal effect on credit markets as the Government competes for investment funds to finance its deficits and related governmentsponsored operations.

\section{Impacts of Fiscal Policy}

I thought that it might be helpful if I turn directly to some of the more recent, and controversial, instances of the use of fiscal policy. Events following the tax cut of 1964 seemed to verify the predictability of fiscal policy in promoting, as forecasted, a substantial expansion in the nation's output and employment. The belated tax increase of 1968 did not quite live up to that earlier standard of predictability in terms of producing the forecasted behavior in total spending.

The reasons are complex and deserve careful study. It does seem to me that disillusionment with fiscal policy, while understandable, is decidedly premature. My own analysis of the experience with the imposition of the income tax surcharge in 1968 convinces me that changes in taxation do have a visible impact on the allocation of personal income among consumption, taxation, and saving. The available data do show that increases in income taxes, temporary or permanent, do have the desired effects; they do tend - as would be expected - to depress both personal consumption expenditures and personal saving.

However, the precise proportions of these impacts, as we have seen, may vary according to the changing influence of many factors, including consumer expec- 
tations conceming the future. Hence, the repercussions may be more modest than had been expected, at least by some analysts, but the results seem to me to be quite clear. A complicating consideration in analyzing the repercussions nay be the swamping of effects from tax changes because other factors were operating. This does not mean that the tax changes, per se, were not effective; they may merely be hidden under the surface of more dramatic events.

For example, consumer spending averaged 78.2 per cent of personal income in the eighteen months before the Federal income tax surcharge was enacted in July 1968, and 77.3 per cent in the 18 months after that tax increase became effective. If we make what often is the heroic assumption that all other factors were held constant, it would appear that the 10 per cent surcharge caused the proportion of personal income which was devoted to consumption to decline by nine-tenths of one percentage point. Similarly, the proportion of income saved dropped by 1.3 percentage points.

A somewhat more sophisticated analysis would make some allowance for the lags that may occur between the time that personal income is changed and a shift in consumer spending patterns is evident. For example, the authoritative study at the University of Michigan by George Katona and Eva Mueller of the 1964 tax legislation revealed a lag between tax action and personal spending of perhaps 6 months or more. For purposes of illustration, let us assume a more modest three-month lag for the temporary 10 per cent increase in Federal income tax rates enacted in 1968.

Hence, let us analyze the relationship between consumer spending and saving in a given quarter of a year and the income received in the preceding quarter. On that basis (see Table 1), the imposition of the incone tax surcharge was followed by a drop of 1.2 percentage points in the proportion of personal

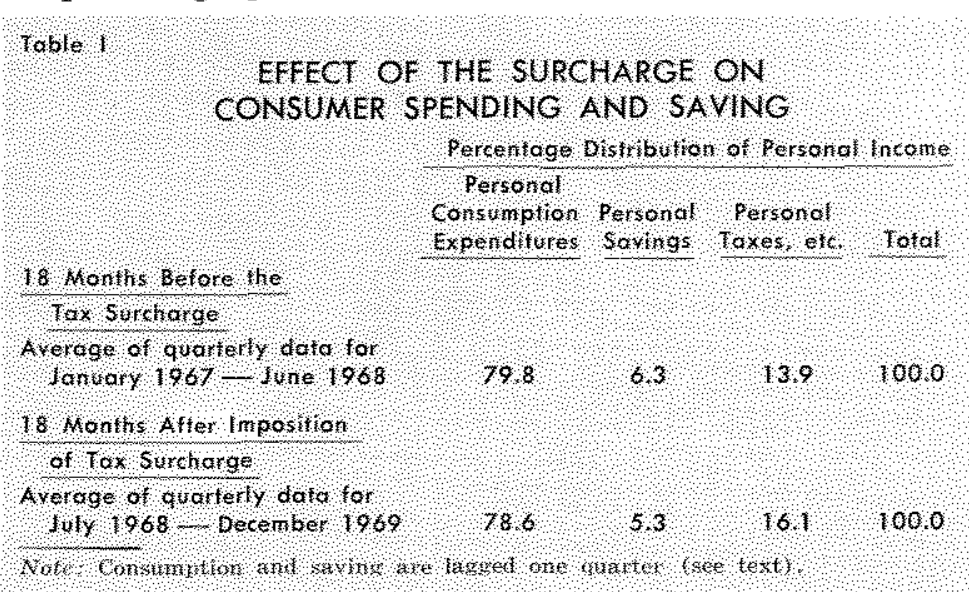

income devoted to personal consumption expenditures, and a decline of one percentage point in the savings ratio for the time periods under study, In an economy the size of our own, a one percentage point shift is quite striking when we translate it into billions of dollars.

I suggest that, in retrospect, the direct economic impact of the surcharge was as we should have expected: the major share of the higher taxes came out of funds that consumers otherwise would have devoted to personal consumption expenditures, and the remainder came out of income that would otherwise have been saved and invested. To me, this experience vindicates rather than discredits the usefulness of fiscal policy for purposes of economic stabilization.

Our experience to date with the phase-out of the surcharge tends to confirm the pattem of adjustment. Both consumer spending and consumer saving have risen as a proportion of personal income, and, here again, a lagged reaction may be developing. The impact on saving seems to have been greater in the immediate period than it is likely to be in subsequent months when consumers have had time to adjust their consumption pattems to their higher disposable income. Hence, we can expect the savings ratio to recede somewhat from its current peak. Certainly, the phase-out of the surcharge has contributed to the higher level of economic activity and, together with appropriate monetary policy, has enabled us to make the current economic adjustment to a less inflationary economy without the customary recession.

Hence, the current wave of skepticism concerning the effectiveness of fiscal policy seems quite ill-advised, and I do sense its ebbing. Although fiscal measures have helped to slow down the economy, what neither fiscal nor monetary restraint has done was to arrest quickly a strong inflationary momentum. This should provide a sobering experience for advocates in either camp.

To this observer, one clear lesson of the last few years is the importance of the Federal fiscal position to monev and capital markets. Federal deficits at high employment spell trouble in terms of overstrained financial markets and upward pressures on interest rates.

To be sure, a distinction between "passive deficits" (resulting from economic slowup) and "active deficits" (to stimulate economic growth) still can be made. As economic 
slowup develops, Federal receipts fall, and, indeed, this was a factor in the more-than-projected deficit of the past fiscal year. This has meant more Federal financing and more pressure in financial markets, already feeling the effects of continuing heavy private requirements for liquidity. Interest rates, of course, nevertheless have subsided somewhat - but not yet in as substantial a degree as has characterized many other cyclical slowups. The small declines of yields in both short- and long-term markets have been one manifestation of this.

And, as long as the economic adjustment now underway remains small, as it has, the pressure in financial markets will place limits to the decline in yields. The risk is now tuming in the other direction - to higher yields, should the recovery now apparently in progress move up too fast. Unfortunately, this could channel the flow of funds to sectors other than those with high national priority - allocation of credit to housing, state and local governments, small businessmen, etc.

Hence, appropriate fiscal policy in an economy of high employment must play a strategic role; the links between fiscal and monetary policies are complex and unbreakable.

Some fiscal skeptics fail to see how a few billion dollars - of govemment money - can matter one way or another. What some of the critics forget is that the extra Federal borrowing, while small relative to total output, impinges on credit markets whose short-run capacity is limited. This can be disruptive in terms of the functioning of markets, the allocation of credit among different classes of borrowers (e.g., for home mortgages), and the level of interest rates.

We do need to recognize the practical limitations under which fiscal policy operates. There are serious barriers to very frequent changes for short-run stabilization purposes. Political restraints may at times result in an inappropriate fiscal policy. Certainly, the $\$ 25$ billion budget deficit in the fiscal year 1968 was a mark of wrong, but not of ineffectual, fiseal policy. In retrospect, we would have hoped that fiscal effects then were weaker than they actually were.

To sum up, there are many sides to the economic elephant, around which economists are stumbling and of which we are taking various measurements. Money matters, as do fiscal actions. The state of our economic knowledge does not justify a doctrinaire dismissal of either stabilization policy approach. We have too few effective economic policy tools to be in a position to abandon any,

Indeed, as we examine economic policy in recent periods, we do indeed find that we have continued to utilize fiscal tools. For example, at the President's request, the Congress passed several revenue-raising measures last year which were designed to assist in dampening down a then overheated economy.

The items that I have in mind include extending the 10 per cent income tax surcharge from June 30 , 1969 to December 31, 1969, and, at a five per cent rate, to June 30,1970 . Also, scheduled reductions in selected excises were postponed one year (and the Administration has asked that these tax reductions be postponed again).

It is clear to me that fiscal measures continue to play an important, but not solitary, role in the execution of national economic policy.

\section{Federal-State-Local Relations}

I would like to tum briefly to an aspect of fiscal and economic policy that often is overlooked in dis. cussions of national trends - the interrelationships between the Federal Government and state and local governments. The Federal Government, as we know, possesses rather potent monetary and fiscal tools which it can use to help promote economic stabilization and growth.

In contrast, state and local governments, far more limited in their fiscal capabilities, are more in the position of reacting to aggregate economic trends. Many local governments, for example, find themselves in a budgetary bind when so much of their income comes from sources not responsive to economic growth, such as the property tax.

Mindful of the financial problems facing state and local governments, the Nixon Administration has advanced an innovative program for sharing a portion of Federal revenues with states, counties, and cities. Under the revenue-sharing proposal, a percentage of the Federal personal income tax base - the fairly steadily rising total of individual taxable incomes reported to the Internal Revenue Service - will be disbursed each quarter to every state, county, and city in the nation.

Although revenue sharing will not be a panacea, it should help to strengthen the capability of state and local governments to respond to the needs of their citizens. 


\section{The Outlook}

My own reading of the economic tea leaves leads me to believe that the economy is in the process of turning up while inflationary pressures are being reduced. However, it is important during this period of transition to keep the inevitable month-to-month fluctuations in their proper perspective.

For the period immediately ahead, each month's statistics are not likely to steadily reflect an uptum in the level of economic activity nor a downward trend in the rate of inflation. In fact, a short pause or even a temporary tum for a month or so in some of these statistical series is quite likely and, in some cases, has been occurring. We need to avoid confus. ing these volatile and temporary fluctuations with changes in the underlying trend.

It is when we examine these underlying trends that we find the basis for the expectations of advancement in the level of economic activity and a continued reduction in the rate of price increases. Perhaps the major and very real change that we have been witnessing is in the general atmosphere of improved expectations.

Despite the current strike in the automobile industry, I anticipate that real GNP will rise in the third quarter of 1970 . The results for the fourth quarter will depend in good measure on the extent to which the strike will continue. In any event, I would expect the current work stoppage merely to slow down or interrupt the recovery which is already under way.

My own evaluation of the economic outlook leads me to conclude that the uptum will be moderate enough to be accompanied by continued measureable progress in bringing down the rate of inflation. The performance of both consumer prices and wholesale prices in recent months is quite reassuring on that score: ignoring inevitable month-to-month fluctuations, the trend in 1970 to date shows a dampening in the rate of inflation. My forecast for the coming year is along the same lines: ignoring inevitable month-to-month fluctuations, the outlook is for a further dampening in the rate of inflation. The specific degree of improvement in the price level, of course, will depend in part on the results of decisions in the private sector on wages and other elements of costs and prices.

Given this background of economic developments, the budget situation is a source of considerable attention. It is too early for any definitive statement on the prospects for the fiscal year 1971. There are still actions which can, and should, be taken on both the revenue and expenditure sides which would hold down the likely deficit to reasonable proportions.

The budget rule announced by the President on recent occasions certainly provides a good and clear guide: to keep expenditures within the limits of the revenues that our Federal tax structure provides at full employment. By following this guideline, we will restore budgetary balance when the economy is operating at full potential.

Keeping expenditures within full employment rev enues will not be easy to do, especially if new initiatives are to be pursued, let alone the general updrift in costs of existing programs. It is likely to require hard decisions on the expenditure side-perhaps some program deferrals, reductions and phase-outs.

In the area of military spending, the leading indicators all portend a continued slowdown in dollar terms and a further decline in real terms in coming months. In the longer run, the trend of defense expenditures will depend on the course of international developments and this nation's reaction to them.

In the area of civilian government outlays, I am struck by the cogency of the recent warning of Caspar Weinberger, the Deputy Director of the Office of Management and Budget: "A pilot project normally turns into an essential program in three years ... The distance from an urgent priority to an untouchable sacred cow is usually no more than five fiscal years."

A fiscal policy adequate and proper for the transition to a period of renewed growth but lessened inflationary pressures calls for a tighter control over Federal spending. To keep expenditures within the revenues that can be expected when the economy returns to full employment will require hard choices among alternative spending programs.

There is much talk these days about the need to change our priorities. But, there are two parts to the process. The attractive and much easier part of increasing spending for high priority items has, as we would expect, received the great bulk of the attention. We now need to focus on the second and harder step which is necessary in order to achieve the required shift of resources: identifying those programs of lower priority which can be reduced, postponed, or even eliminated and then taking action to do so. Not until this second step is accomplished will the necessary changes in priorities truly be effected. 